\title{
Increased Blood Lipid Level is Associated with Cancer-Specific Mortality and All-Cause Mortality in Patients with Colorectal Cancer ( $\geq 65$ Years): A Population-Based Prospective Cohort Study [Retraction]
}

\author{
Yang Y, Gao G, Shi J, Zhang J. Risk Manag Healthc \\ Policy. 2020;13:855-863.
}

The Editor-in-chief and Publisher of Risk Management and Healthcare Policy wish to retract the published article. Following a review of the article by The Irish Longitudinal Study on Ageing (TILDA) investigation team, it was found the numbers reported in the study with colorectal cancer to be inaccurate, with a sample far higher than that reported with colorectal cancer in the TILDA public archive. Thus, the observations and findings reported in the study were not supported by the TILDA dataset.
Despite several attempts, the authors could not be contacted for an explanation and the decision was made to retract the article.

Our decision-making was informed by our policy on publishing ethics and integrity and the COPE guidelines on retraction.

The retracted article will remain online to maintain the scholarly record, but it will be digitally watermarked on each page as "Retracted".

\section{Publish your work in this journal}

Risk Management and Healthcare Policy is an international, peerreviewed, open access journal focusing on all aspects of public health, policy, and preventative measures to promote good health and improve morbidity and mortality in the population. The journal welcomes submitted papers covering original research, basic science, clinical \& epidemiological studies, reviews and evaluations, guidelines, expert opinion and commentary, case reports and extended reports. The manuscript management system is completely online and includes a very quick and fair peer-review system, which is all easy to use. Visit http://www.dovepress.com/testimonials.php to read real quotes from published authors. 